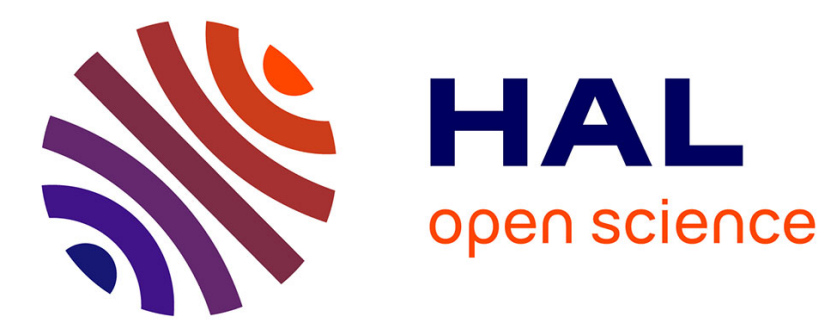

\title{
Identification of a new stilbene-derived inducer of paraoxonase 1 and ligand of the Aryl hydrocarbon Receptor.
}

Erwan Guyot, Xavier Coumoul, Jean-François Chassé, Farid Khallouki, Jean François Savouret, Marc Poirot, Robert Barouki

\section{To cite this version:}

Erwan Guyot, Xavier Coumoul, Jean-François Chassé, Farid Khallouki, Jean François Savouret, et al.. Identification of a new stilbene-derived inducer of paraoxonase 1 and ligand of the Aryl hydrocarbon Receptor.. Biochemical Pharmacology, 2012, 83 (5), pp.627-632. 10.1016/j.bcp.2011.12.013 . inserm00743456

\section{HAL Id: inserm-00743456 https://www.hal.inserm.fr/inserm-00743456}

Submitted on 22 Jul 2019

HAL is a multi-disciplinary open access archive for the deposit and dissemination of scientific research documents, whether they are published or not. The documents may come from teaching and research institutions in France or abroad, or from public or private research centers.
L'archive ouverte pluridisciplinaire HAL, est destinée au dépôt et à la diffusion de documents scientifiques de niveau recherche, publiés ou non, émanant des établissements d'enseignement et de recherche français ou étrangers, des laboratoires publics ou privés. 
Title: Identification of a new stilbene-derived inducer of Paraoxonase 1 and ligand of the Aryl hydrocarbon Receptor.

Authors: Erwan Guyot ${ }^{1,2^{*}}$, Xavier Coumoul ${ }^{1,2^{*}}$, Jean-François Chassé ${ }^{1,2}$, Farid Khallouki ${ }^{4,5,6}$ Jean François Savouret ${ }^{1,2}$, Marc Poirot ${ }^{4,5,6^{*}}$, Robert Barouki ${ }^{1,2,3^{*}}$

\section{Addresses:}

${ }^{1}$ INSERM UMR-S 747, Toxicologie Pharmacologie et Signalisation Cellulaire, 45 rue des Saints Pères, 75006 Paris France

${ }^{2}$ UNIVERSITE Paris Descartes, Paris Sorbonne Cité, Centre universitaire des Saints-Pères, 45 rue des Saints Pères, 75006 Paris France

${ }^{3}$ AP-HP, Hôpital Necker-Enfants Malades, service de biochimie métabolique, 149, rue de Sèvres, 75743 Paris, France

${ }^{4}$ INSERM UMR-1037, Centre de recherche sur le Cancer de Toulouse, Toulouse, France

${ }^{5}$ Université Paul Sabatier, Toulouse, France

${ }^{6}$ Institut Claudius Regaud, Toulouse France

* Both authors contribute equally to this work

Corresponding authors: $\operatorname{Pr}$ Robert Barouki, telephone: +33142862072, robert.barouki@parisdescartes.fr; Pr Xavier Coumoul, telephone: +33142863359, xavier.coumoul@parisdescartes.fr

Keywords : Paraoxonase 1, Resveratrol, Aryl hydrocarbon Receptor, stilbene structure, screening. 


\begin{abstract}
Paraoxonase 1 (PON1) is a high-density lipoprotein-associated enzyme, synthesized in the liver and secreted into the blood. PON1 displays antioxidant properties and is involved in organophosphorous compounds and oxidized lipids degradation. Because of these beneficial effects, pharmacological regulation of PON1 appears to be highly relevant in toxicology and cardiology. Recent studies undertaken on the regulation of the PON1 promoter in our laboratory have identified resveratrol, through its activation of the Aryl hydrocarbon Receptor (AhR), as a putative inducer of PON1. We have tested a new modulator of AhR, (Z)-2,3-bis (4-nitrophenyl)-acrylonitrile, and established that it is a more potent inducer of PON1 at the mRNA, protein and enzymatic activity as compared to resveratrol. It also acts by activating the AhR. However, in contrast with traditional AhR agonists, it does not induce cyp1A1 transcription. (Z)-2,3-bis (4-nitrophenyl)-acrylonitrile is therefore a specific AhR modulator targeting PON1.
\end{abstract}




\section{Introduction}

Paraoxonase 1 (PON1) is an HDL-associated enzyme, which is synthesized in the liver. It was first characterized by its ability to hydrolyze organophosphorous (OP) compounds such as the insecticide paraoxon but it also hydrolyzes chemical warfare nerve agents such as soman. The enzyme has also been shown to be protective in the case of OP pesticides exposure [1]. More recently, a cardiovascular protective role has been suggested [2]. The latter role has been associated with different enzymatic properties of PON1: degradation of oxidized lipids [3], hydrolysis of homocystein thiolactone [4], and decreased cholesterol biosynthesis in macrophages [5]. Several polymorphisms of the PON1 gene have been identified in humans. These polymorphisms contribute to important inter-individual variations of PON1 [6]. In particular, polymorphisms located in the PON1 promoter are positively associated with higher concentrations of PON1 in the serum and with an increased risk of arterial ischemic stroke [7].

In light of the potentially protective role of PON1, the regulation of its gene has been extensively studied. Several factors, including commercial drugs, have been shown to regulate the level of PON1 [8]. For example, the exposure of human $\mathrm{HuH7}$ cells to bezafibrate or fenofibric acid increases the level of PON1 mRNA as well as PON1 activity. The effect of statins on the regulation of $P O N 1$ (pravastatin, simvastatin and fluvastatin) is controversial. Indeed, two studies described increased levels of PON1 in serums of patients treated with simvastatin or atorvastatin $[9,10]$. However, simvastatin did not exhibit any potential of increasing PON1 in HuH7 cells [12]. Other molecules with potential cardiovascular protective effects have been evaluated for their effects on PON1. For example, several natural polyphenols including quercetin and resveratrol stimulate PON1 activity. We have shown that the induction of paraoxonase 1 by polyphenols requires the transcription factor AhR (Aryl hydrocarbon Receptor). The AhR is a xenobiotic-activated receptor and a transcriptional regulator of enzymes involved in the metabolism of xenobiotics. The AhR forms a cytosolic complex with several heat shock proteins. Upon ligand binding, AhR translocates into the nucleus, and, following dissociation of the heat shock proteins, it binds to the nuclear protein ARNT (AhR Nuclear Translocator). The AhR/ARNT heterodimer binds to Xenobiotic Responsive Elements (XRE) located in the promoters of target genes [12]. Interestingly, a variant XRE has been identified in the promoter of PONI [13]. Other studies have shown a link between the activation of the AhR and the induction of PON1. For example, aspirin 
increases PON1 expression in several cellular and animal models (HepG2, Sprague-Dawley rat hepatocytes, C57BL6 mice) but fails to induce PON1 in AhR-/- mice [14].

In order to identify a more potent inducer of PON1 than resveratrol, we designed several resveratrol-derived compounds as a continuing effort to develop AhR selective modulators. We describe here the properties of (Z)-2,3-bis (4-nitrophenyl)-acrylonitrile as a more potent inducer of PON1 as compared to resveratrol in the human hepatic cell line $\mathrm{HuH} 7$. Further, we show that this derivative activates the AhR. 


\section{Materials and Methods}

\subsection{Chemicals}

TCDD was purchased from LCG Promochem (Molsheim, France). Benzo(a)pyrene, $3 \mathrm{MC}$ and quercetin were purchased from Sigma-Aldrich (St Louis, USA). Resveratrol was purchased from Cayman chemical (Ann Harbor, USA). (Z)-2,3-bis (4-nitrophenyl)acrylonitrile (ZNPA) synthesized will be described elsewhere (Khallouki et al, in preparation).

\subsection{Cell culture}

Human hepatocarcinoma HuH7 cells were maintained in Dulbecco's minimal essential medium (DMEM, Invitrogen, Cergy-Pontoise, France) supplemented with nonessential amino acids and containing $10 \%$ fetal bovine serum (FBS), $200 \mathrm{U} / \mathrm{mL}$ penicillin, $50 \mu \mathrm{g} / \mathrm{mL}$ streptomycin (Invitrogen, Life Technologies SAS, Villebon sur Yvette, France) and $0.5 \mathrm{U} / \mathrm{mL}$ amphotericin B (Bristol-Myers Squibb Co., Stamford, USA) at $37{ }^{\circ} \mathrm{C}$ in a humidified atmosphere with $5 \% \mathrm{CO} 2$. The $\mathrm{HuH} 7$ stably-transfected cell line (stable construction: the firefly luciferase gene controlled by the human promoter of PON1, [12]) was maintained like the original cell line which was added by $0.6 \mathrm{~g} / \mathrm{L} \mathrm{G} 418$ (Invitrogen).

\subsection{Luminescence assay}

Cells were seeded in 24 -well plates (80 000 cells/well). One day later, cells were treated. After cell lysis with $100 \mu \mathrm{L}$ of phosphate lysis buffer (Promega, Charbonnières, France), cell lysates were centrifugated for $5 \mathrm{~min}$ at $10000 \mathrm{rpm}$. Ten $\mu \mathrm{L}$ of supernatant were deposited in 96 well microtiter plates. Then, $50 \mu \mathrm{L}$ of luciferine (Luciferase assay reagent, Promega, Charbonnière, France) were added just before measurements were made. Luciferase activity measurements were performed $48 \mathrm{~h}$ after treatment, with a Wallac 2101 EnVisionTM Multilabel Reader (Perkin Elmer).

\subsection{RNA extraction, reverse transcription and quantitative RT-PCR}

Total RNAs were extracted using the RNeasy mini kit (Qiagen, Les Ulis, France) and reverse transcription was performed with each RNA sample using the cDNA high-capacity archive kit (Applied Biosystems, Courtaboeuf, France). Primers used for the real time PCR were: PON1: forward 5'-CATAAAAGTGCTCAGGTCCCACAG-3' and reverse 5'- 
TGGAATTGGGGATCACTGGAAG-3'; AhR: forward 5'-ACATCACCTACGCCAGTCGC-

3' and reverse 5'-TCTATGCCGCTTGGAAGGAT-3'; Cyp1A1: forward 5'GACCACAACCACCAAGAAC - $3^{\prime}$ and reverse 5'- AGCGAAGAATAGGGATGAAG -3' ; RPL13A: forward 5'-CCTGGAGGAGAAGAGGAAAGAGA-3' and reverse 5'GAGGACCTCTGTGTATTTGTCAA-3'. Oligonucleotides were obtained from (Qiagen). Quantitative RT-PCR was carried out in a $10 \mu \mathrm{L}$ reaction volume containing $40 \mathrm{ng}$ of cDNA, $300 \mathrm{nM}$ of each primer and ABsolute ${ }^{\mathrm{TM}}$ QPCR SYBR ${ }^{\circledR}$ Green (Abgene, Villebon sur Yvette, France). Quantitative RT-PCR measurements were performed on an ABI Prism 7900 Sequence Detector system (Applied Biosystems). PCR cycles consisted of the following steps: Taq activation $\left(15 \mathrm{~min}, 95^{\circ} \mathrm{C}\right)$, denaturation $\left(15 \mathrm{~s}, 95^{\circ} \mathrm{C}\right)$ annealing and extension $\left(1 \mathrm{~min}, 60^{\circ} \mathrm{C}\right)$. The threshold cycle $(\mathrm{Ct})$, which is inversely correlated to the amount of target mRNA, was measured as the number of cycles for which the reporter fluorescent emission first exceeds the background. The relative amounts of mRNA were estimated using the $\Delta \Delta \mathrm{Ct}$ method [15] with the ribosomal protein L13a (RPL13A) transcripts as reference.

\subsection{Measurement of PON1 activity}

$\mathrm{HuH} 7$ cells were treated at day 0 with $5 \mu \mathrm{M}$ ZNPA (or DMSO $0.1 \%$ used as control condition); medium was changed on day 2 and cells were re-treated with $5 \mu \mathrm{M}$ ZNPA (or DMSO 0.1\%). Measurements of PON1 arylesterase activities were performed on day 4, in conditioned medium using $5 \mathrm{mmol} / \mathrm{L}$ phenylacetate (Sigma-Aldrich) as substrate in Tris- $\mathrm{HCl}$ $50 \mathrm{mmol} / \mathrm{L}, \mathrm{pH} 8$ buffer containing $1 \mathrm{mmol} / \mathrm{L} \mathrm{CaCl}_{2}$. The reaction was followed by recording the optical density at $270 \mathrm{~nm}$ (appearance of phenol) for $10 \mathrm{~min}$ at $35^{\circ} \mathrm{C}$ with a PowerWaveX (Biotek instruments) microplate reader using KC4 software (Biotek, colmar, France). All the measurements were corrected using a negative control (non-enzymatic hydrolysis). The activity of PON1 is expressed as $\triangle \mathrm{OD} 270 / \mathrm{min}$.

\subsection{Immunofluorescence experiments}

$\mathrm{HuH7}$ cells were seeded onto glass coverslips (150 000 cells per well in 6-well plates) $24 \mathrm{~h}$ before transfection with $1 \mu \mathrm{g}$ of expression vector for eGFPc1-AhR [16]. Treatments (TCDD, $5 \mathrm{nM} ; \mathrm{ZNPA}, 5 \mu \mathrm{M}$ or DMSO) were carried out for $24 \mathrm{~h}$ later. After one hour treatment, the coverslips were washed twice in PBS and then fixed with 4\% paraformadehyde (Sigma-Aldrich, St Louis, USA) for $10 \mathrm{~min}$ in the dark at room temperature. The coverslips were sealed with Vectashield mounting medium (Abcys, Paris, France) containing 4,6- 
diamidino-2-phenylindole (Vector Laboratories, Inc, Burlingame, CA, USA) which stains the nucleus (blue). Images were acquired using a Nikon Eclipse TE-2000 E microscope.

\subsection{Statistics}

Student's two-tailed $t$ tests were performed with Statview software (Abacus concepts, Inc.) to analyze the results and these ones are expressed as the mean \pm standard deviation of at least three independent experiments. A p-value $<0.05$ was considered as statistically significant $(* * * \mathrm{p}<0,001 ; * * \mathrm{p}<0,01 ; * \mathrm{p}<0,05)$. 


\section{Results}

Human hepatic $\mathrm{HuH7}$ cells are frequently used to study PON1 regulation (e.g [17]), [18]). As a first step, we used a stably transfected $\mathrm{HuH7}$ cell line previously established in our laboratory [12], which bears a PON1 promoter controlling the Firefly luciferase gene (Figure 1A). This cell line was exposed to several resveratrol derivatives and luciferase expression was measured 48h later, similarly to our former studies [19]. Resveratrol has been chosen for different reasons. First, its chemical structure is easy to chemically modify. The hydroxy groups, which might be partly responsible for its antioxydant effects, have been removed and nitro and cyano groups have been added on this background skeleton (classical chemical modifiers used in drug design) to generate several resveratrol derivatives. We also used several traditional AhR ligands (3-MC, BaP, TCDD) as controls, and a polyphenol, which also activate the AhR (resveratrol) (Figure 1B). PON1 was induced by 3-methylcholantrene (3-MC, $5 \mu \mathrm{M}, 3.5$ fold) whereas TetraChloro-Dibenzo-para-Dioxin (TCDD, the prototypical AhR ligand) did not activate the promoter of PON1 (Figure 1B), in agreement with our previous studies. The natural polyphenol resveratrol (Resv) also induced PON1 (Figure 1B). For the screening of the reservatrol-based derivatives, we used concentrations of $1 \mu \mathrm{M}$ in order to identify the most potent compounds. In contrast with resveratrol, (Z)-2,3-bis(4nitrophenyl)-acrylonitrile (ZNPA) (Figure 1C), has no affinity for the estrogen receptors, does not inhibit tyrosine kinases, does not contain phenolic groups which account for the resveratrol antioxidant properties but is a high affinity ligand of the AhR ( $\mathrm{Ki}=12.8 \pm 6 \mathrm{nM})$ (Khallouki et al, manuscript in preparation).

We next assessed the effect of ZNPA on PON1 promoter by measuring the activity of the luciferase reporter gene in the stably-transfected $\mathrm{HuH7}$ cell line. Whereas resveratrol (10 $\mu \mathrm{M})$ and ZNPA $(1 \mu \mathrm{M})$ induced this activity 2- to 3-fold, ZNPA (10 $\mu \mathrm{M})$ elicited more than a 7-fold induction (Figure 1D).We next evaluated the effects of ZNPA on the regulation of the endogenous PON1 mRNA. We used the original HuH7 cell line. After 48h of exposure of HuH7 cells to ZNPA, PON1 mRNAs were assayed by quantitative RT-PCR and were shown to be significantly increased by this compound. Using this assay, we performed a dose response curve, which showed that the $\mathrm{EC}_{50}$ of $\mathrm{ZNPA}$ was around $1 \mu \mathrm{M}$, (Figure $2 \mathrm{~A}$ ). The half-life of PON1 mRNA (about 15h in $\mathrm{HuH} 7$ cells) was not modified by exposure of the cells to resveratrol or to ZNPA (data not shown). 
We next measured the enzymatic activity of paraoxonase 1 in $\mathrm{HuH7}$ cells following

their exposure to ZNPA. PON1 is secreted by the cells into the medium where its activity can be quantified. HuH7 cells were exposed to ZNPA for 96h (to allow synthesis and secretion of the protein). Because the basal level of PON1 activity is very high in supernatants from cells maintained with $10 \%$ fetal bovine serum (FBS), the experiment was carried in the absence of $10 \%$ FBS. We found a significant increase of PON1 activity following exposure of the cells to ZNPA treatment (Figure 3).

We previously demonstrated that resveratrol induces the expression of PON1 through activation of the Aryl hydrocarbon Receptor. We hypothesized that ZNPA could have a similar mechanism of action. Thus, a possible link between the AhR and ZNPA was investigated. The usual AhR agonist/antagonist classification is not adequate to explain PON1 induction. Indeed, $3 \mathrm{MC}$ and TCDD are considered to be AhR agonists when cytochrome P450 1A1 (CYP1A1) induction is concerned, but produce different effects on PON1 regulation. Conversely, resveratrol which is considered to be an AhR antagonist, induces PON1 gene expression. If TCDD binds the AhR without any effects on PON1 regulation, we hypothesized that TCDD could antagonize the effect of ZNPA. Since TCDD induces CYP1A1 mRNA in cellular models, we analyzed the expression of CYP1A1 and PON1 mRNA following exposure of HuH7 cells to TCDD and/or ZNPA. CYP1A1 mRNA is induced approximately 3-fold following exposure of cells to ZNPA (for both 1 and $5 \mu \mathrm{M}$ ) (Figure 4A). This induction is very weak compared to that observed following exposure to TCDD alone (about 100-fold at $5 \mathrm{nM}$ ). However, co-exposure to ZNPA, partially prevents the TCDD-mediated induction of CYP1A1. There is a significant $25 \%$ decrease with $1 \mu \mathrm{M}$ ZNPA and about a $40 \%$ decrease with $5 \mu \mathrm{M}$ ZNPA. In contrast, PON1 is induced following treatment of cells with ZNPA and TCDD alone has no effect. However, exposure of cells concomitantly to TCDD abolishes the induction of PON1 by ZNPA (Figure 4B). We next investigated whether ZNPA is able to induce the translocation of the AhR into the nucleus. Nuclear translocation of the AhR was observed in $\mathrm{HuH7}$ cells transfected with an expression vector of the AhR tagged with the Green Fluorescent Protein (GFP) following exposure for one hour to 5nM TCDD (positive control) or to $5 \mu \mathrm{M}$ ZNPA (Figure 5). All these results suggest that ZNPA activates the translocation of the AhR into the nucleus and the AhR-dependent transcription of PON1. 


\section{Discussion}

Resveratrol displays important pharmacological properties such as its cardioprotective, anti-ageing and metabolic effects. Although it was initially believed that these effects were predominantely related to its antioxidant properties, it appears that this compound can also act through alternative mechanisms to modulate gene expression. Most of these effects have been observed in vitro within a wide range of concentrations [20]. Among its numerous effects, it has been demonstrated that resveratrol activates 5 ' adenosine monophosphate-activated protein kinase (AMPK) [21] and Sirtuin 1 SIRT1, a NADdependent deacetylase, the activity of which has been associated with protection against metabolic diseases in mice [22]. Resveratrol may be considered also as a phytoestrogen as it has been demonstrated that this molecule binds estrogen receptors, albeit with relatively low affinity [23]. Further, it has been demonstrated that resveratrol is able to prevent the effects of AhR agonists like $\mathrm{BaP}$ [24] or TCDD [25] on CYP1A1 gene expression with a potency that is similar to that of $\alpha$-naphtoflavone [26]. Other polyphenols have also been described as AhR ligands and as either antagonists or partial agonists for CYP1A1 induction. Some polyphenols were shown to be able to induce the PONI gene expression through the activation of the AhR [12]. An alternative responsive element has been identified in the promoter of PONI and siRNA-based experiments have clearly demonstrated the role of the AhR as the mediator. Importantly, there was no clear correlation between the agonist or antagonist activity of these polyphenols on CYP1A1 induction and their inducing effect on PON1. Our studies with ZNPA further confirmed this discrepancy.

The identification of a pharmacological inducer of this PON1 gene expression is important from a therapeutic standpoint. Our strategy was to start from resveratrol, as a parent drug, to design derivatives and then to test the ability of these derivatives to induce PON1. Among two sets of synthesized molecules, we identified one compound, ZNPA, as a novel bona fide inducer of PON1 which is a new selective AhR ligand (ref Khallouki et al, in preparation). ZNPA was able to induce both the mRNA levels and the activity of PON1 at concentrations lower than those of resveratrol. It should be noted that a compound named dinitrostilben, which has a structure similar to ZNPA (except for the nitrile group), does not induce PON1. Similarly to resveratrol, ZNPA antagonizes the effect of TCDD on CYP1A1 regulation. Conversely, TCDD acts as a pharmacological inhibitor of PON1 induction by ZNPA. The competition between TCDD and ZNPA as well as the nuclear translocation of the 
AhR following ZNPA treatment suggest the implication of this receptor in ZNPA action. We hypothesize that the chemical nature of the ligand affects the structure of the AhR and its ability to bind specific DNA sequences which are different in the case of the PON1 and CYP1A1 gene promoters. In the consensus XRE (GCGTG), the AhR and ARNT bind to GC and GTG, respectively. In the alternative responsive elements identified in the promoter of the PON1 gene promoter, The ARNT binding subsite is different (GGG instead of GGG). This suggests either that ARNT might not be the AhR partner involved in the regulation of PON1 or that its binding is indirectly altered by ZNPA. One of the biggest challenges will be to determine how ligands affect the chemical structure of the AhR to influence partner and DNA binding. These studies support our hypothesis for a structural plasticity of the AhR which could account for its different functions in the presence of different ligands..

The results presented here support the notion that the usual AhR agonist/antagonist classification of compounds might not be relevant to indicate their effect on PON1. Indeed, we show that ZNPA is a very weak CYP1A1 inducer (its potency is $2 \%$ that of TCDD) and the strongest inducer of PON1 that we have been able to test to date. In that sense, ZNPA, as an AhR ligand, is highly but not completely selective of PON1. It should be mentioned that in absolute terms, ie the absolute induction fold of CYP1A1 and PON1, ZNPA appears to be equally active. However, CYP1A1 is a very highly inducible gene whereas PON1 is at best a moderately regulated gene. Therefore, relative induction values appear to be more relevant to determine selectivity. The concept of selective AhR modulators was recently defined and it may account for the anti-cancer and anti-inflammatory properties of certain AhR ligands [30] [31]. We believe that the mechanism of PONI regulation by ZNPA and resveratrol is highly relevant to challenge this concept.

In addition to the AhR, the regulation of PON1 also involves other transcription factors. Indeed, SREBP2 (sterol regulatory element-binding protein-2) [10], PPAR $\gamma$ [28] and Sp1 [29] are involved in the modulation of the PONI gene promoter activity. It is possible that the activation of different pathways would enhance PON1 gene expression. In that case, a combination of compounds activating different signaling pathways could be required to obtain a maximal induction of this gene and thereby an improved pharmacological action.. Further investigations will be needed, however, to determine other key features involved in the induction of PON1. 


\section{References}

[1] Davies HG, Richter RJ, Keifer M, Broomfield CA, Sowalla J, Furlong CE. The effect of the human serum paraoxonase polymorphism is reversed with diazoxon, soman and sarin. Nat Genet. 1996;14:334-6.

[2] Tward A, Xia YR, Wang XP, Shi YS, Park C, Castellani LW, Lusis AJ, Shih DM. Decreased atherosclerotic lesion formation in human serum paraoxonase transgenic mice. Circulation 2002;106:484-90

[3] Mackness MI, Arrol S, Durrington PN. Paraoxonase prevents accumulation of lipoperoxides in low-density lipoprotein. FEBS Lett. 1991;286:152-4. Erratum in: FEBS Lett $1991 ; 292: 307$

[4] Perla-Kaján J, Jakubowski H. Paraoxonase 1 protects against protein Nhomocysteinylation in humans. FASEB J. 2010;24:931-6.

[5] Rozenberg O, Shih DM, Aviram M. Human serum paraoxonase 1 decreases macrophage cholesterol biosynthesis: possible role for its phospholipase-A2-like activity and lysophosphatidylcholine formation. Arterioscler Thromb Vasc Biol. 2003;23:461-7

[6] Richter R. J. and Furlong, C. E. Determination of paraoxonase (PON1) status requires more than genotyping. Pharmacogenetics 1999;9:745-753

[7] Deakin SP, James RW. Genetic and environmental factors modulating serum concentrations and activities of the antioxidant enzyme paraoxonase-1. Clin Sci. 2004;107:435-47.

[8] Soran H, Younis NN, Charlton-Menys V, Durrington P. Variation in paraoxonase1 activity and atherosclerosis. Curr Opin Lipidol. 2009;20:265-74.

[9] Deakin S, Leviev I, Guernier S, James RW. Simvastatin modulates expression of the PON1 gene and increases serum paraoxonase: a role for sterol regulatory element-binding protein-2. Arterioscler Thromb Vasc Biol. 2003;23:2083-9. 
[10] Nagila A, Permpongpaiboon T, Tantrarongroj S, Porapakkham P, Chinwattana K,

Deakin S, Porntadavity S. Effect of atorvastatin on paraoxonase1 (PON1) and oxidative status. Pharmacol Rep. 2009;61:892-8.

[11] Gouédard C, Koum-Besson N, Barouki R, Morel Y. Opposite regulation of the human paraoxonase-1 gene PON-1 by fenofibrate and statins. Mol Pharmacol. 2003;63:94556.

[12] Barouki R, Coumoul X, Fernandez-Salguero PM. The aryl hydrocarbon receptor, more than a xenobiotic-interacting protein. FEBS Lett. 2007;581:3608-15.

[13] Gouédard C, Barouki R, Morel Y. Dietary polyphenols increase paraoxonase 1 gene expression by an aryl hydrocarbon receptor-dependent mechanism. Mol Cell Biol. 2004;24:5209-22.

[14] Jaichander P, Selvarajan K, Garelnabi M, Parthasarathy S. Induction of paraoxonase 1 and apolipoprotein A-I gene expression by aspirin. J Lipid Res. 2008;49:21428.

[15] Pierre S, Bats AS, Chevallier A, Bui LC, Ambolet-Camoit A, Garlatti M, Aggerbeck M, Barouki R, Coumoul X. Induction of the Ras activator Son of Sevenless 1 by environmental pollutants mediates their effects on cellular proliferation. Biochem Pharmacol. 2011;81:304-13.

[16] Widerak M, Ghoneim C, Dumontier MF, Quesne M, Corvol MT, Savouret JF. The aryl hydrocarbon receptor activates the retinoic acid receptoralpha through SMRT antagonism. Biochimie. 2006;88:387-97.

[17] Arii K, Suehiro T, Ikeda Y, Kumon Y, Inoue M, Inada S, Takata H, Ishibashi A, Hashimoto K, Terada Y. Role of protein kinase $\mathrm{C}$ in pitavastatin-induced human paraoxonase I expression in Huh7 cells. Metabolism. 2010;59:1287-93.

[18] Garige M, Gong M, Varatharajalu R, Lakshman MR. Quercetin up-regulates paraoxonase 1 gene expression via sterol regulatory element binding protein 2 that translocates from the endoplasmic reticulum to the nucleus where it specifically interacts with 
sterol responsive element-like sequence in paraoxonase 1 promoter in $\mathrm{HuH7}$ liver cells. Metabolism. 2010;59:1372-1378.

[19] Gouédard C, Barouki R, Morel Y. Induction of the paraoxonase-1 gene expression by resveratrol. Arterioscler Thromb Vasc Biol. 2004;24:2378-83.

[20] Baur JA, Sinclair DA. Therapeutic potential of resveratrol: the in vivo evidence. Nat Rev Drug Discov. 2006;5:493-506.

[21] Baur JA, Pearson KJ, Price NL, Jamieson HA, Lerin C, Kalra A, Prabhu VV, Allard JS, Lopez-Lluch G, Lewis K, Pistell PJ, Poosala S, Becker KG, Boss O, Gwinn D, Wang M, Ramaswamy S, Fishbein KW, Spencer RG, Lakatta EG, Le Couteur D, Shaw RJ, Navas P, Puigserver P, Ingram DK, de Cabo R, Sinclair DA. Resveratrol improves health and survival of mice on a high-calorie diet. Nature. 2006;444:337-42

[22] Lagouge M, Argmann C, Gerhart-Hines Z, Meziane H, Lerin C, Daussin F, Messadeq N, Milne J, Lambert P, Elliott P, Geny B, Laakso M, Puigserver P, Auwerx J. Resveratrol improves mitochondrial function and protects against metabolic disease by activating SIRT1 and PGC-1alpha. Cell. 2006;127:1109-22.

[23] Bowers JL, Tyulmenkov VV, Jernigan SC, Klinge CM. Resveratrol acts as a mixed agonist/antagonist for estrogen receptors alpha and beta. Endocrinology. 2000;141:3657-67.

[24] Revel A, Raanani H, Younglai E, Xu J, Rogers I, Han R, Savouret JF, Casper RF. Resveratrol, a natural aryl hydrocarbon receptor antagonist, protects lung from DNA damage and apoptosis caused by benzo[a]pyrene. J Appl Toxicol. 2003;23:255-61.

[25] Singh SU, Casper RF, Fritz PC, Sukhu B, Ganss B, Girard B Jr, Savouret JF, Tenenbaum HC. Inhibition of dioxin effects on bone formation in vitro by a newly described aryl hydrocarbon receptor antagonist, resveratrol. J Endocrinol. 2000;167:183-95.

[26] Casper RF, Quesne M, Rogers IM, Shirota T, Jolivet A, Milgrom E, Savouret JF. Resveratrol has antagonist activity on the aryl hydrocarbon receptor: implications for prevention of dioxin toxicity. Mol Pharmacol. 1999;56:784-90 
[27] Cirla A, Mann J. Combretastatins: from natural products to drug discovery. Nat Prod Rep. 2003;20:558-64.

[28] Khateeb J, Gantman A, Kreitenberg AJ, Aviram M, Fuhrman B. Paraoxonase 1 (PON1) expression in hepatocytes is upregulated by pomegranate polyphenols: a role for PPAR-gamma pathway. Atherosclerosis. 2010;208:119-25.

[29] Osaki F, Ikeda Y, Suehiro T, Ota K, Tsuzura S Arii K. Roles of Sp1 and protein kinase $\mathrm{C}$ in regulation of human serum paraoxonase 1 (PON1) gene transcription in HepG2 cells. Atherosclerosis. 2004;176: 279-287.

[30] Safe S, McDougal A. Mechanism of action and development of selective aryl hydrocarbon receptor modulators for treatment of hormone-dependent cancers (Review). Int $\mathbf{J}$ Oncol. 2002;20:1123-8.

[31] Murray IA, Morales JL, Flaveny CA, Dinatale BC, Chiaro C, Gowdahalli K, Amin S, Perdew GH. Evidence for ligand-mediated selective modulation of aryl hydrocarbon receptor activity. Mol Pharmacol. 2010;77:247-54. 


\section{Figure legends}

Figure 1 : a) Schematic representation of the stably-transfected reporter gene used for the screening. $1.009 \mathrm{bp}$ of the PON1 proximal promoter were subcloned in a luciferase expressing plasmid [9]. b) Effects of AhR ligands on the stably-transfected cell-line. Luciferase activity measurements were performed at $48 \mathrm{~h}$ and are expressed as ratios (mean \pm $\mathrm{SD} ; \mathrm{n} \geq 5$ ). Results, represented as fold-inductions, show significant inductions with different treatments (3-methylcholantrene $(3 \mathrm{MC})$ at $5 \mu \mathrm{M}$ and resveratrol at $10 \mu \mathrm{M})(* * * \mathrm{p}<0,001 ; *$ $\mathrm{p}<0,05)$. c) Representation of the chemical structure of $(Z)-2,3-b i s(4-n i t r o p h e n y l)-$ acrylonitrile (ZNPA). d) Effects of selected compound ZNPA compared to resveratrol (Resv) on the stably-transfected cell-line. Luciferase activity measurements were performed at $48 \mathrm{~h}$ and are expressed as ratios (luciferase activities measures of the control condition have been fixed to 1). Results are represented as fold-inductions and show significant inductions with the different treatments (mean $\pm \mathrm{SD} ; \mathrm{n} \geq 3$ ). Similar response levels are observed with Resv $10 \mu \mathrm{M}$ and ZNPA $1 \mu \mathrm{M}$ and a significant higher level compared to these treatments, is obtained with ZNPA $10 \mu \mathrm{M} . \varnothing$ indicates that no statistical difference has been found between the two conditions

Figure 2 : Effects of different concentrations of ZNPA on the expression of PON1 mRNA . mRNA of HuH7 cells were recovered after $48 \mathrm{~h}$ of treatments (concentrations of ZNPA between $10^{-8}$ and $10^{-5} \mathrm{M}$ were used and are represented on a semi-log scale) and then reverse transcriptions were performed. Quantitative PCR were employed to evaluate levels of relative expression of PON1 mRNA and allowed to establish a dose response curve (mean \pm SD; $n=3)$. 
Figure 3 : Measurements of secreted PON1 activities. HuH7 cells were treated at day 0 with $5 \mu \mathrm{M}$ ZNPA (or DMSO $0.1 \%$ used as control condition), and retreated with $5 \mu \mathrm{M}$ ZNPA at day 2 (or DMSO 0.1\%). Measurements of PON1 arylesterase activities were performed at day 4. Results are expressed in $\Delta \mathrm{OD}_{270} /$ min (mean $\left.\pm \mathrm{SD} ; \mathrm{n}=4\right)$. Significant higher level is observed for PON1 activity measured in the supernatants from ZNPA treated cells $(\mathrm{p}<0.05)$.

Figure 4 : a) Antagonistic effects of ZNPA on the induction of CYP1A1 mRNA generated by a treatment with TCDD. HuH7 cells were treated with ZNPA or/and TCDD. mRNA were recovered after $48 \mathrm{~h}$ of treatments. Reverse transcriptions and quantitative RTPCR were performed to measure the relative CYP1A1 levels. Results are expressed in percentage of level of CYP1A1 mRNA obtained with TCDD treatment (mean \pm SD; $n=4$ ). Levels of CYP1A1 mRNA obtained with treatments with ZNPA $1 \mu \mathrm{M}$ and $5 \mu \mathrm{M}$ (respectively 2.8- and 2.4-fold induction over control) alone are very weak compared to level reached with TCDD 5nM treatment (104.9-fold induction over control). Treatments with ZNPA caused a dose-dependent decrease on the induction of CYP1A1 mRNA generated by a treatment with TCDD (respectively 79.7- and 63.7-fold induction over control).

b)Antagonistic effects of TCDD on ZNPA PON1 mRNA induction. HuH7 cells were treated with ZNPA or/and TCDD. mRNA were recovered after $48 \mathrm{~h}$ of treatments and then reverse transcriptions were performed. Quantitative PCR were employed to evaluate levels of relative expression of PON1 mRNA. Results are expressed in percentage of level of PON1 mRNA obtained with ZNPA $1 \mu \mathrm{M}(1.8$-fold induction over control) treatment (mean $\pm \mathrm{SD}$; $\mathrm{n}=4)$. Treatment with TCDD at 5nM has no significant effect on PON1 mRNA level (0.8-fold induction over control) and abrogates the induction of PON1 mRNA caused by a treatment with ZNPA at $1 \mu \mathrm{M}$ (1.0-fold induction over control). 
Figure 5 : Effects of ZNPA treatment on the nuclear translocation of the AhR. HuH7 cells have been transfected with an expression plasmid of an AhR-GFP. Then, these cells were treated with three conditions (DMSO as the negative control, TCDD at $5 \mathrm{nM}$ as a positive control and ZNPA at $5 \mu \mathrm{M})$. Cells were fixed with $4 \%$ paraformadehyde before the acquisition of these images. Nuclei are stained with DAPI. The presence of the AhR-GFP is observed in both cytoplasmic and nuclear compartments with each treatment but the signal is far more stronger for cells treated with TCDD and ZNPA. 
Figure 1a.

$[-1013]$

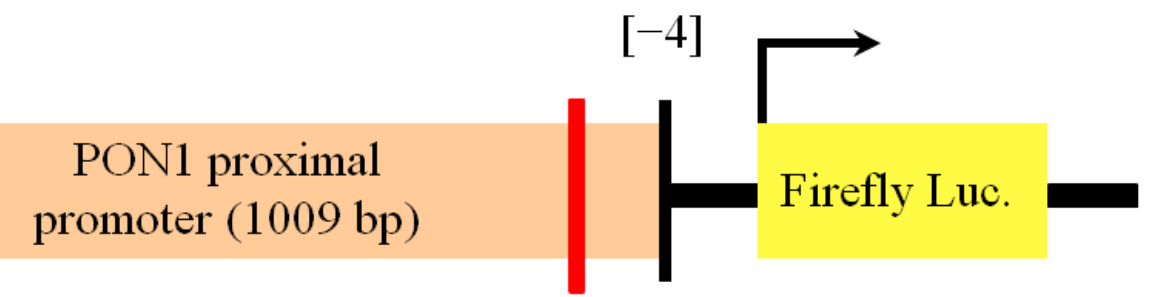

[ -112 to -108$]$

Alternative XRE

(a)

(Gouedard et al., 2004)

(the +1 position corresponds to the $\mathrm{A}$ of the start codon) 
Figure 1b

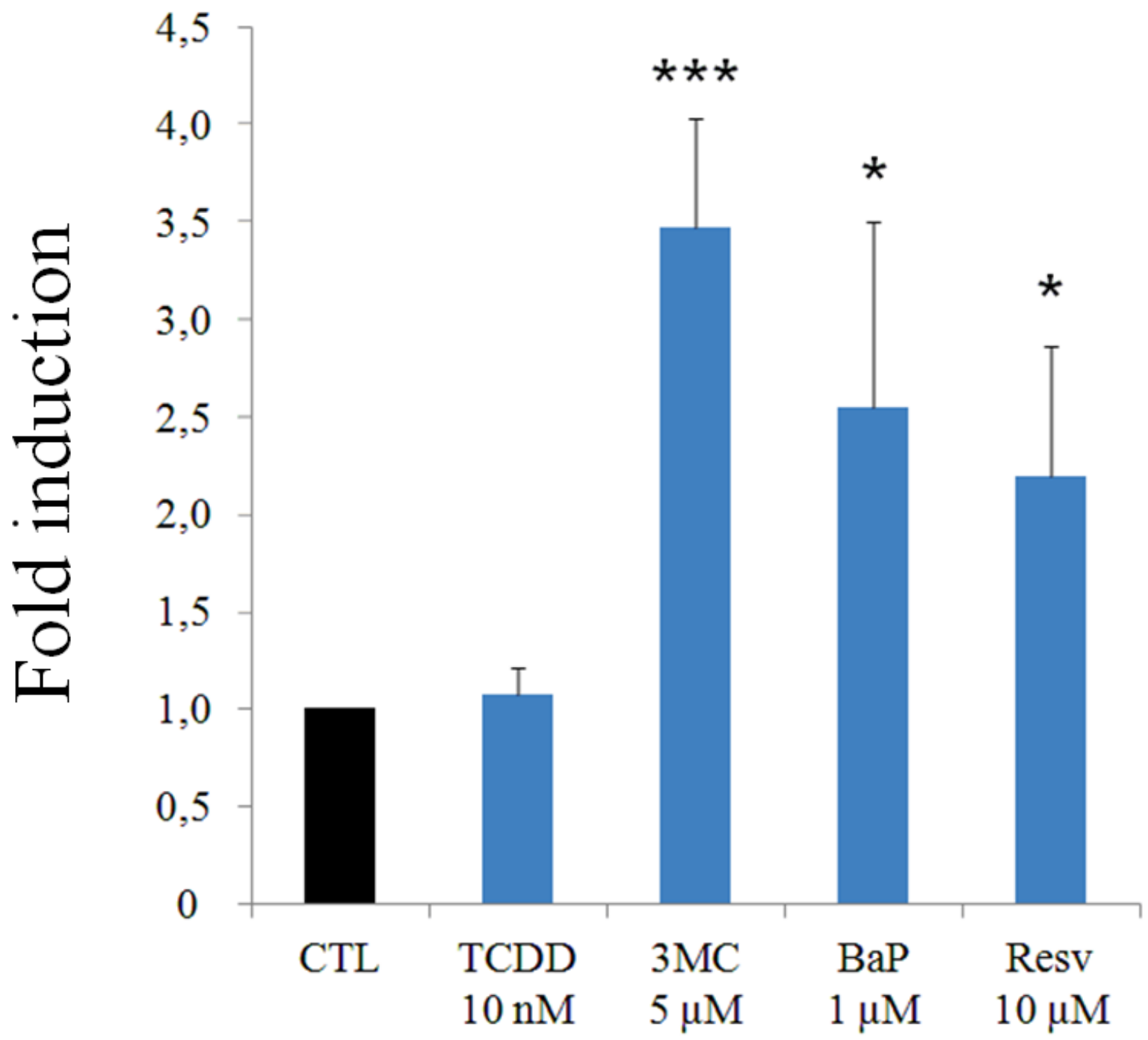


Figure 1c.

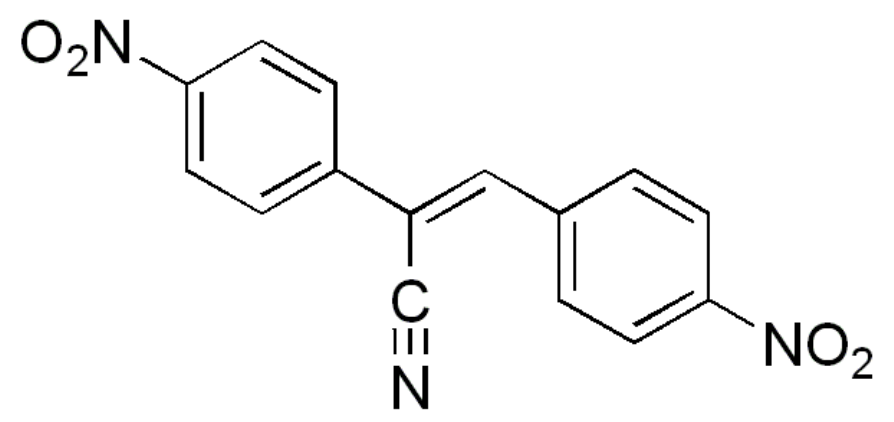


Figure 1d.

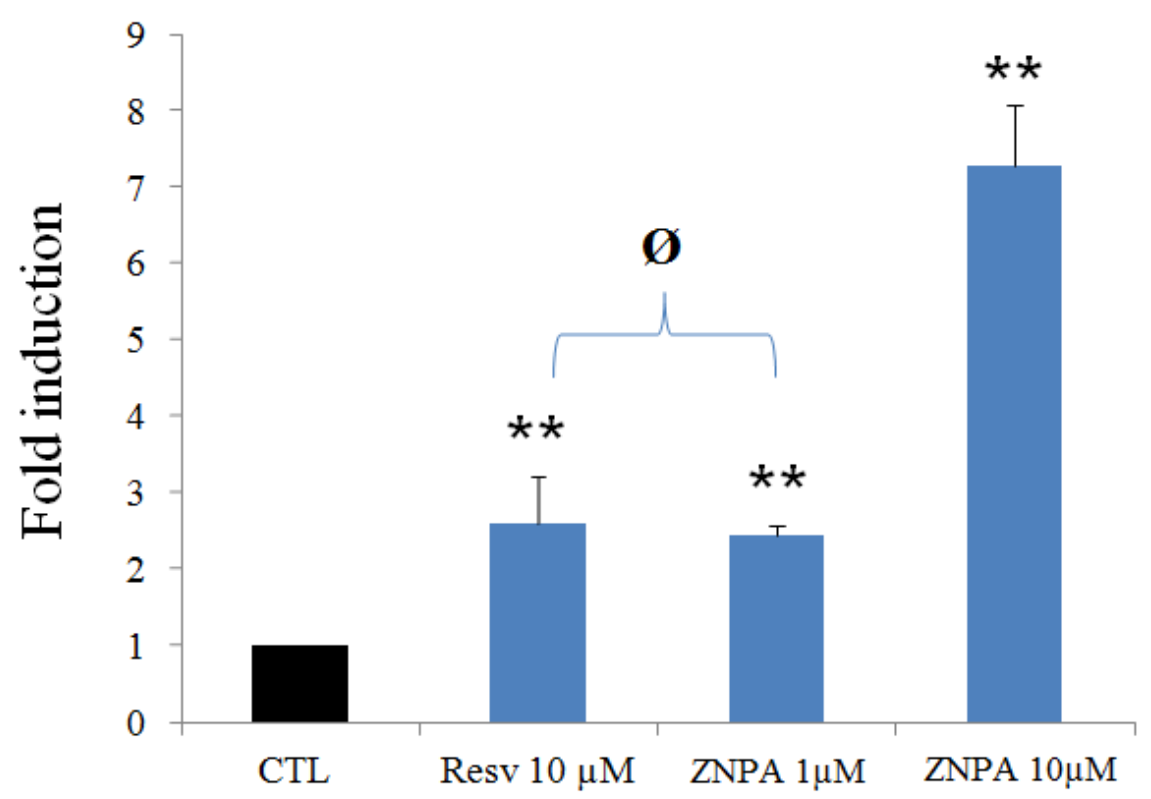


Figure 2

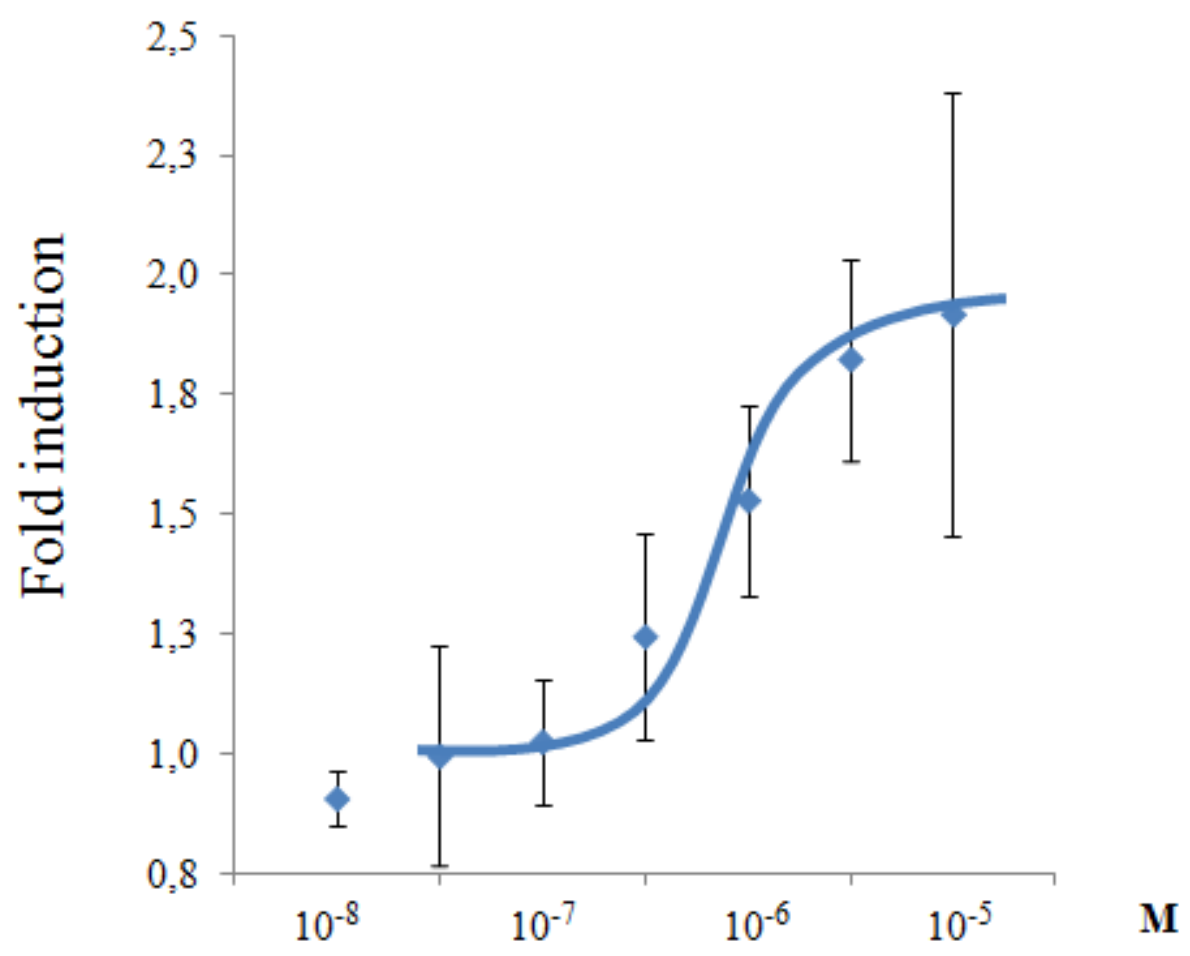


Figure 3

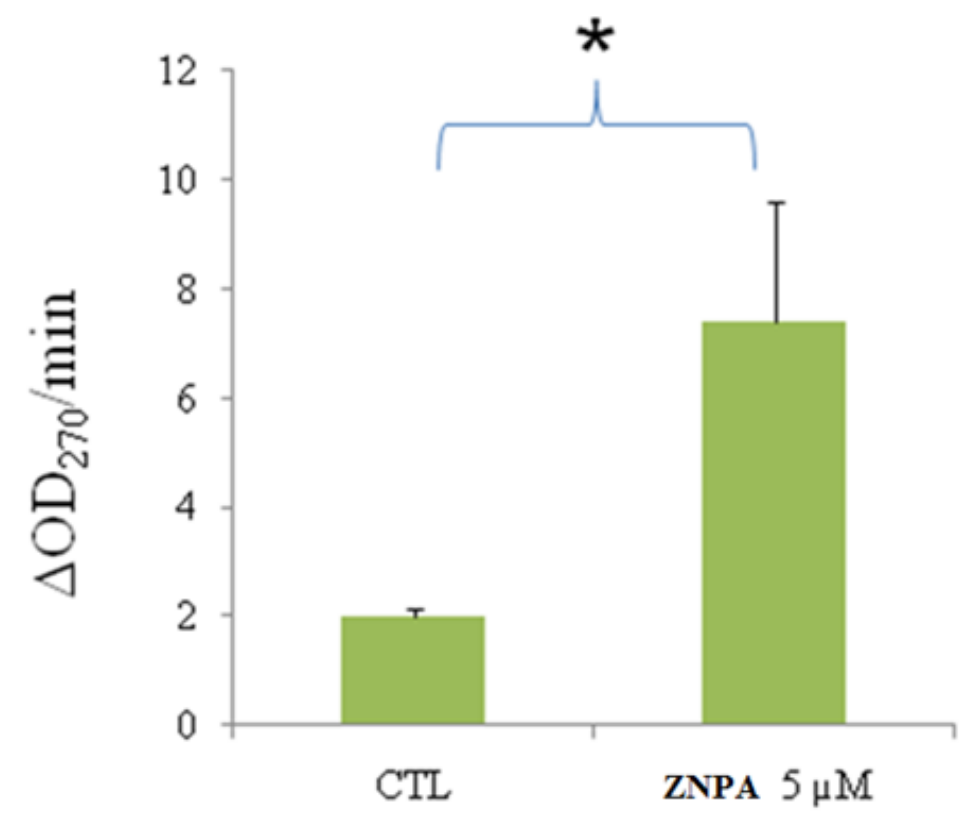


Figure 4A

$\star \star * *$

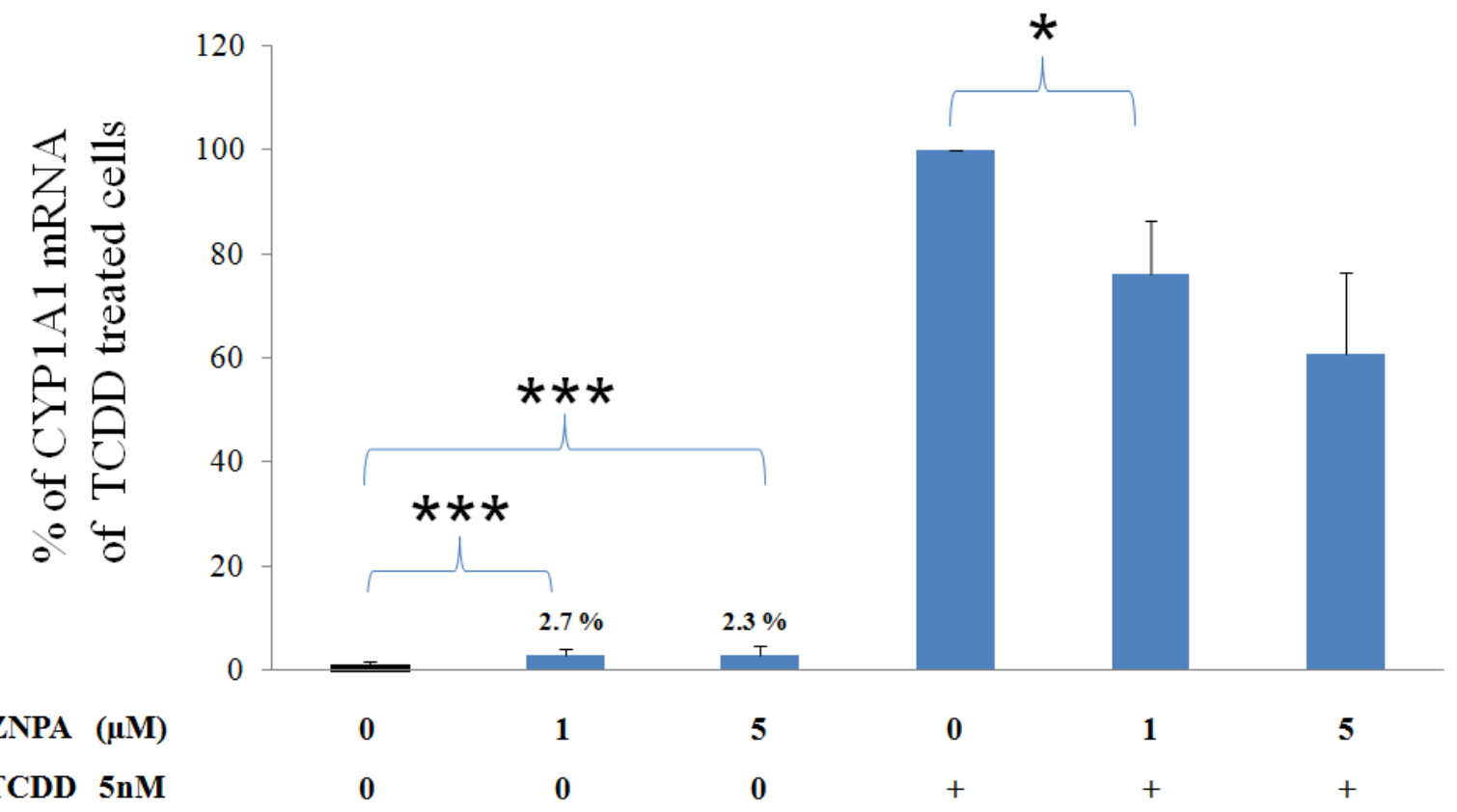


Figure 4B

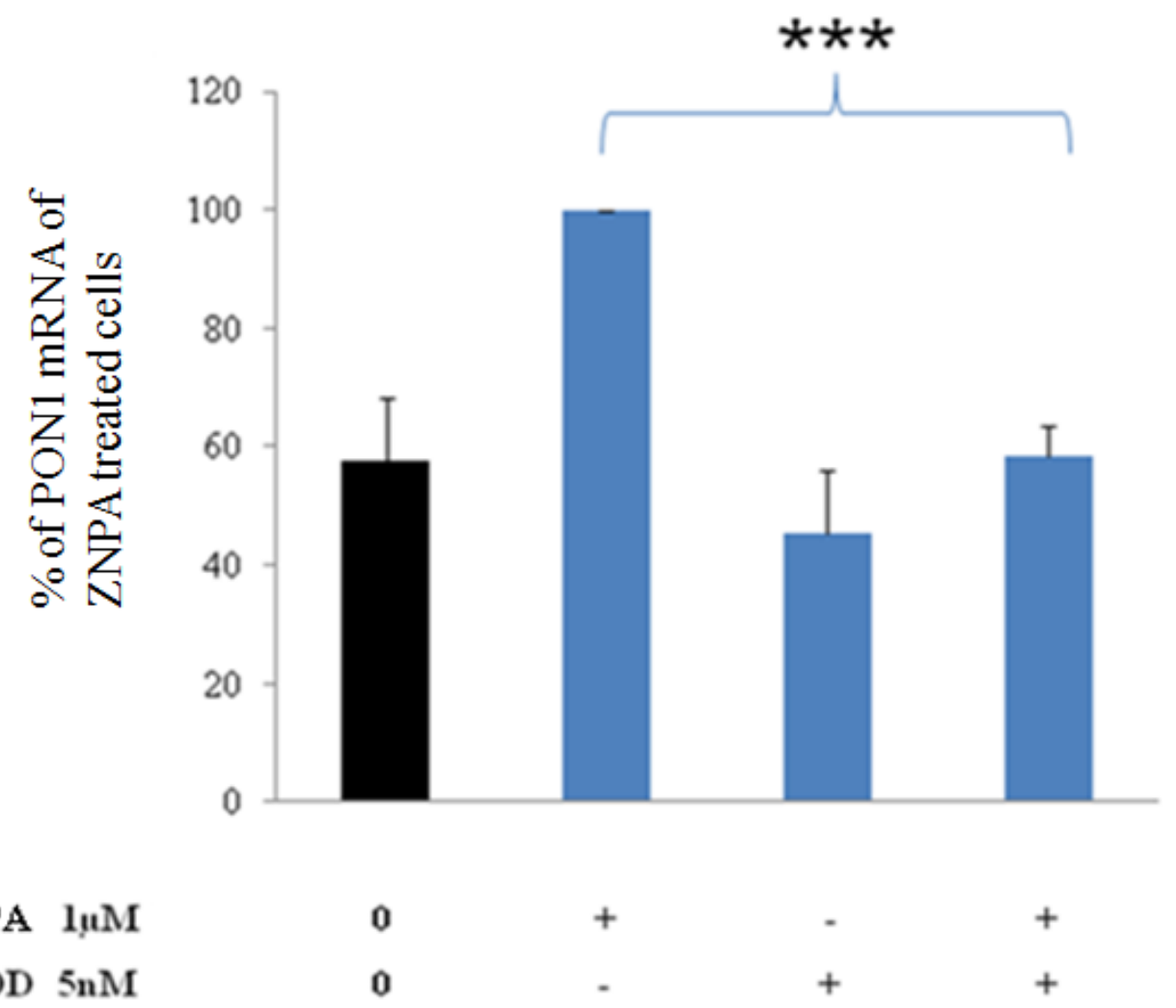


Figure 5.

1

2

3

4

5

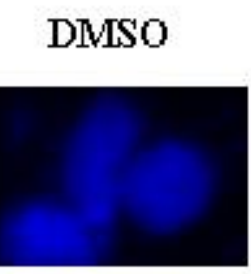

TCDD $5 \mathrm{nM} \quad$ ZNPA $5 \mu \mathrm{M}$

DAPI
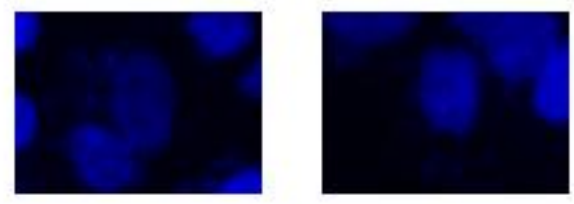

GFP
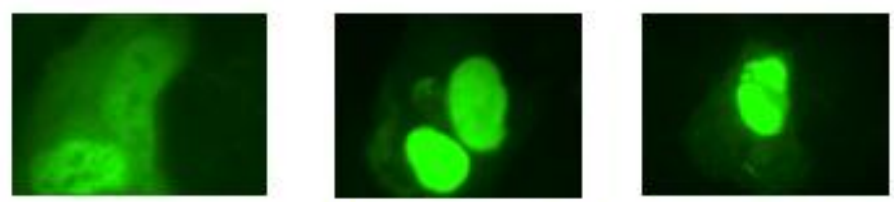

Merge
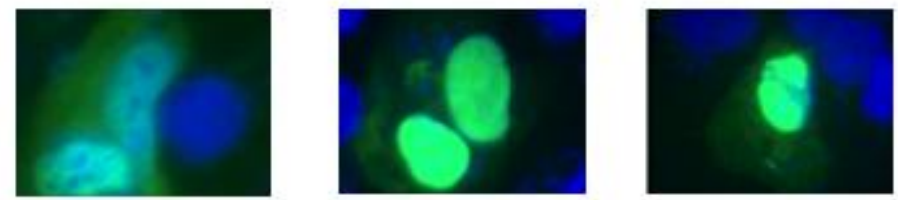
(Z)-2,3-bis (4-nitrophenyl)-acrylonitrile

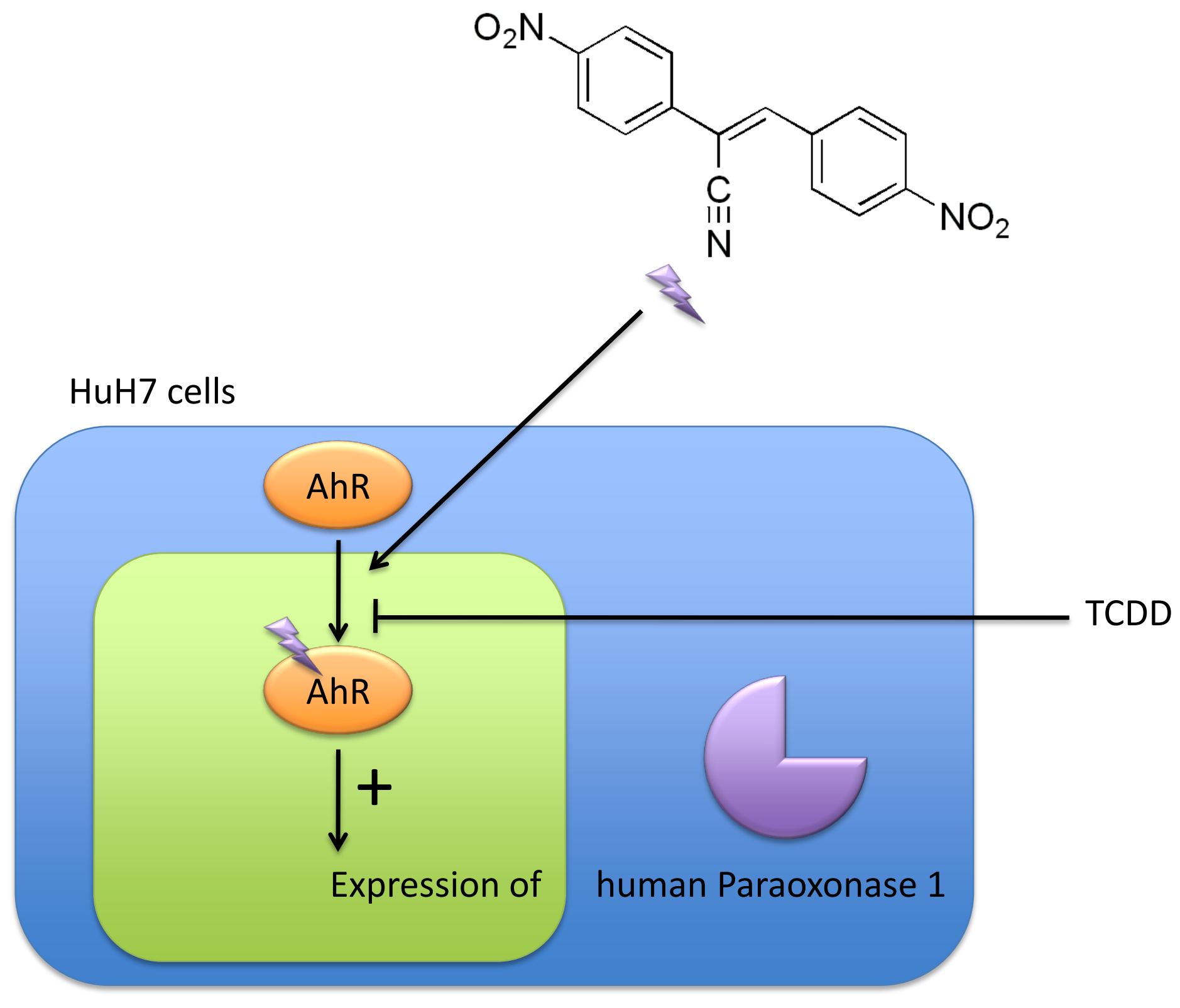

